\title{
MNX1/ETV6 Fusion Gene
}

National Cancer Institute

\section{Source}

National Cancer Institute. MNX1/ETV6 Fusion Gene. NCI Thesaurus. Code C105817.

A fusion gene that results from a chromosomal translocation $t(7 ; 12)(q 36 ; p 13)$ which fuses the first exon of the MNX1 gene with exon 3 of the ETV 6 gene. This aberration is associated with infant acute myeloid leukemia. 